REVISTA ARA Nº. VOlUME 9. PRIMAVERA+VERÃO 2020 • GRUPO MUSEU/PATRIMÔNIO FAU-USP

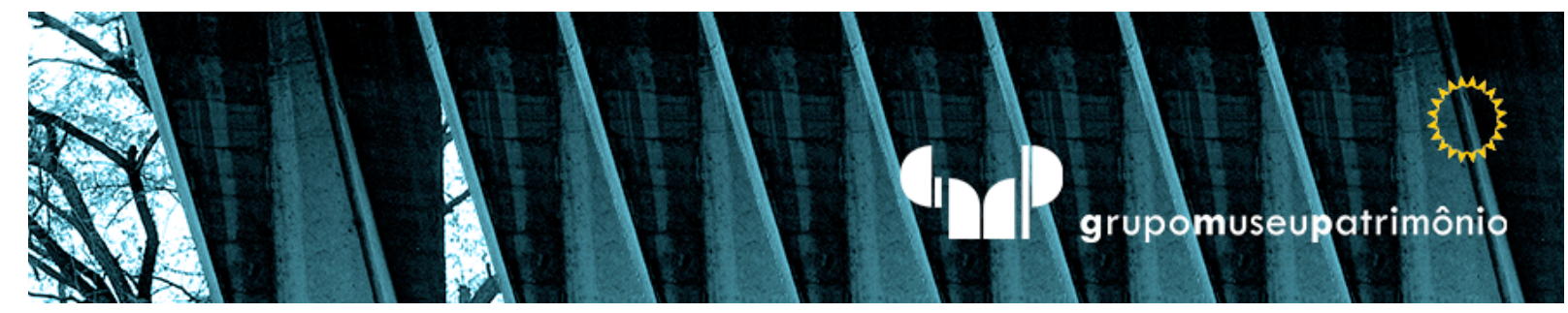

\title{
Imagem sobrevivente
}

\author{
Imagen sobreviviente
}

Surviving image

Paulo Eduardo Barbosa

Doutorando FAU USP e pesquisador do Grupo Museu/Patrimônio GMP FAU USP, São Paulo, Brasil. pebarbosa@usp.br 


\section{Resumo}

Proponho neste artigo a necessidade de se atualizar questões ao se expor em espaço museal conjunto de imagens ampliadas, considerando a expografia como uma das determinantes da possibilidade de análise e fruição da imagem.

Palavras-Chave: imagem. Sintoma. Fantasma. Expografia. recepção

\section{Resumen}

En este artículo, propongo la necesidad de actualizar los problemas exponiendo un conjunto de imágenes ampliadas en un espacio de museo, considerando la expografía como uno de los determinantes de la posibilidad de analizar y disfrutar la imagen.

Palabras clave: Imagen. Síntoma. Fantasma. Expografia. Recepción.

\section{Abstract}

In this article, I propose the need to update issues by exposing a set of enlarged images in a museum space, considering expography as one of the determinants of the possibility of analyzing and enjoying the image.

Keywords: Image. Symptom. Phantasm. Expography. Reception. 
"Ver é sempre uma operação de sujeito, portanto uma operação fendida, inquieta, agitada, aberta." (DIDI-HUBERMAN, 2001, p. 77)

\section{INTRODUÇÃO} urante a coleta de dados relativos à casa sede da Fundação Maria Luísa e Oscar Americano - FMLOA - em 2014, com vistas à realização de palestra no local inserida na programação da Semana de Museus do mesmo ano, tive acesso às imagens do arquivo da $\mathrm{FMLOA}^{1}$ produzidas pelos fotógrafos Leon Liberman e Peter Scheier em 1955/56. Embora a palestra versasse sobre outro tema, as relações entre habitar e visitar uma casa-museu, observei que a excepcional característica técnica e documental das imagens produzidas pelos dois fotógrafos, por encomenda do proprietário da casa, não ensejou, por parte da direção do museu uma inserção qualificada em seu espaço. Entre móveis e objetos do período imperial brasileiro, louças da Companhia das Índias, pinturas de Frans Post e de artistas modernos brasileiros que compõem o acervo da casa,

\footnotetext{
${ }^{1}$ Algumas destas imagens já foram utilizadas em outras publicações, entre elas, na Revista Acrópole no 226 de agosto de 1957 (p. 358-362) e no livro Oswaldo Arthur Bratke de Hugo Segawa e Guilherme Mazza Dourado editado por ProEditores em São Paulo, em 1997.
} 
localizada discretamente próximo à janela da sala principal, sem nenhum destaque, uma pequena haste vertical terminada em superfície de chapa metálica na altura de $90 \mathrm{~cm}$ sustenta um álbum com ampliações tamanho $18 \mathrm{x}$ $24 \mathrm{~cm}$ embaladas em envelopes plásticos. 0 visitante curioso pode folhear 0 álbum que não dispõe de nenhuma legenda indicando autoria ou data das imagens. Os funcionários da casa-museu, muito solícitos, me franquearam o acesso aos arquivos digitais destas imagens para uso acadêmico.

\section{SINTOMA E FANTASMA}

Seja pelo modo selecionado de expor, seja pela farta quantidade de reproduções, estas imagens contidas dentro do espaço do museu oferecem-se à leitura veloz dos visitantes à maneira das sequências disponibilizadas pelos aplicativos digitais dos aparelhos celulares, reproduzindo a busca de algo capaz de proceder a uma captura do sujeito, que possa removê-lo da letargia passiva a que o ambiente esperado do espaço museal o lança, sem desafiar seu horizonte de expectativas, na posição de receptor. Um após o outro, os visitantes que se interessam pelas imagens, folheiam rapidamente o álbum, reiterando a percepção planificada do ambiente da casa-museu no deslocamento entre imagens do passado e o presente da comparação entre o passado e o presente.

De que maneira se poderia permitir que as imagens deste conjunto deixem perceber os rastros, os sintomas que carregam? Certamente não pela observação apressada e hedonista do consumidor contemporâneo, mas pela observação calma e demorada, capaz de revelar questões ali contidas a sinalizar o futuro no modo com que articulam presente e passado, ou, no sentido Warburguiano, sintoma e fantasma.

Para Roger Chartier ${ }^{2}$, a forma infere o sentido, sendo correto pensar que ao se tratar das práticas e representações, os meios pelos quais se constroem a

\footnotetext{
${ }^{2}$ Historiador francês vinculado à historiografia da Escola dos Annales.
} 
relação com o real, visto como referente, alteram e condicionam sua percepção (CHARTIER, 1991). Soma-se a esta afirmação a constatação de que o processo de produção de uma imagem não é isento de seu aspecto discursivo, como apontado por Stuart Hall ${ }^{3}$ para quem a recepção não pode ser entendida apenas em termos comportamentais, mas também "ordenada por estruturas de compreensão [...] produzida por relações econômicas e sociais, que moldam a sua concretização" permitindo que "[...] significados expressos no discurso sejam transpostos para a prática ou a consciência." (HALL, 2003, p.368).

Hall observa que os graus de compreensão e má compreensão na troca comunicativa surgem da falta de equivalência entre os dois lados: codificador/ produtor e decodificador/ receptor e esta lacuna, no caso das imagens da casa ${ }^{4}$ produzidas pelos fotógrafos em $1955 / 56$, estabelece-se também pela expografia. Propõe-se que os arquivos digitais sejam ampliados em grandes formatos e dispostos mantendo certa distância entre elas capaz de permitir a apreciação isolada de cada uma.

Para que possam cumprir certo destino, estas representações demandam condições de observação que propiciem o olhar demorado, lento do receptor, capaz de permitir a percepção da imagem enquanto resultante de '[...] movimentos provisoriamente sedimentados ou cristalizados nela." (DIDIHUBERMAN, 2002, p. 33) Para Georges Didi-Huberman ${ }^{5}$ “[...] ficamos diante da imagem como diante de um tempo complexo, o tempo provisoriamente configurado, dinâmico, desses próprios movimentos." (Id Ibidem, p.34).

Salta aos olhos neste grupo de imagens, a pureza formal característica de certo modernismo brasileiro, próprio do final dos anos 1940 início dos anos 1950, na

\footnotetext{
${ }^{3}$ Antropólogo britânico/jamaicano co-fundador dos Estudos Culturais Bitânicos.

${ }^{4}$ A casa foi projetada pelo arquiteto Oswaldo Bratke para o empresário Oscar Americano.

${ }^{5}$ Filósofo, historiador, crítico de arte e professor da École de Hautes Études en Sciences Sociales, em Paris.
} 
cidade de São Paulo, tempo em que agentes privados ${ }^{6}$ aliam-se ao Estado na afirmação de um devir expresso pela arquitetura, e também por manifestações como as artes plásticas, a música, a dança, entre outras. Para Aby Warburg ${ }^{7}$, a imagem poderia conter uma mistura de coisas passadas e presentes, mesmo na maneira de apontar para o futuro como é o caso deste conjunto.

O conceito de Nachleben utilizado por Warburg pode ser traduzido literalmente como sobrevivência. Para o historiador, entretanto, Nachleben é mais do que isso. É aquilo que faz sentido numa cultura como sintoma, como o anacrônico desta cultura. Warburg toma emprestado este conceito do termo survival utilizado pelo etnólogo britânico Edward B. Tylor. Didi Huberman insiste da diferenciação do conceito de Nachleben daquele do arquétipo, da essência, aproximando-o da ideia de sintoma, traço de exceção, coisa deslocada (DIDI-HUBERMAN 2002, p. 47).

A fotografia das obras construídas tem sido utilizada como meio de duplamente glorificar e inserir a arquitetura moderna entre as artes, haja vista algumas destas imagens aplicadas pelo arquiteto Oswaldo Bratke em sua inscrição ${ }^{8}$ na IV EIA - Exposição Internacional de Arquitetura em maio de 1957 evento integrado à IV Bienal do Museu de Arte Moderna de São Paulo. O intuito de popularizar a arquitetura moderna tornando-a compreensível ao grande público por meio da fotografia instaura entre esta e a arquitetura tensões que se perenizam, desde o catálogo da exposição Brazil builds promovida pelo Museu de Arte Moderna de Nova lorque em 1943 até as imagens ainda hoje veiculadas pelas revistas e sites especializados em arquitetura.

Escala humana eliminada da imagem, graduações de cinzas e ângulos inusitados, estranhos ao observador comum buscam reafirmar a inserção da

\footnotetext{
${ }^{6}$ Neste caso o engenheiro Oscar Americano, próspero engenheiro responsável pela expansão urbana da capital e rodoviária do estado de São Paulo.

${ }^{7}$ Historiador de arte alemão que compôs grande coleção sobre Ciências Humanas transferida em 1933 para Londres, se constituiu a base para criação do Instituto Warburg.

${ }^{8}$ A Casa Oscar Americano no Morumbi, São Paulo recebeu a ficha de inscrição no 204 na IV Exposição Internacional de Arquitetura. Fonte: (HERBST, 2007, p.428)
} 
fotografia na zona de fronteira entre o documento e a construção de outro discurso disposto a propagar de maneira eficaz os três lembretes enviados por Le Corbusier aos arquitetos modernos:

[...] o volume, como elemento pelo qual nossos sentidos percebem e medem, sendo plenamente afetados, a superfície que é o envelope do volume e que pode ampliar ou anular sua sensação, e a planta que é a geradora do volume e da superfície e que é aquilo pelo qual tudo é determinado irrevogavelmente $(2011$, p.9). Grifo do A.

Pode-se dizer que há um deslocamento proposto pela imagem da arquitetura moderna construída pela fotografia evidenciando ideário sobreposto à obra construída. Nas imagens esta operação pode ser atestada, entre outras maneiras, pela valorização de elementos construtivos como pilotis, balanços, texturas e por interiores modernos exemplificando novas alternativas de ambientação possibilitadas pela produção seriada em contraponto aos interiores predominantemente clássicos da burguesia paulistana deste período. 


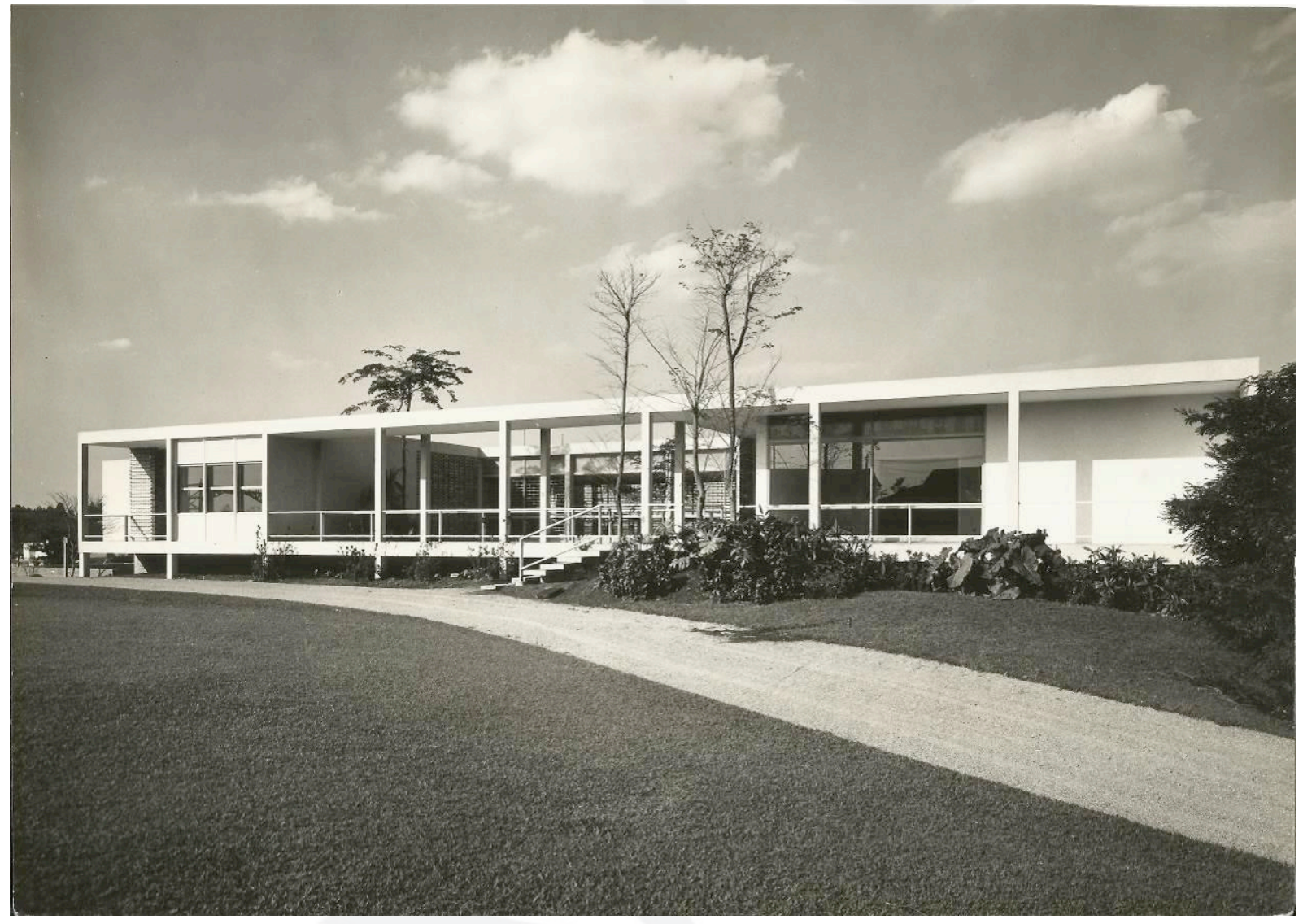

Figura 1: Fachada, Peter Scheier.

Fonte: Arquivo da FMLOA. 


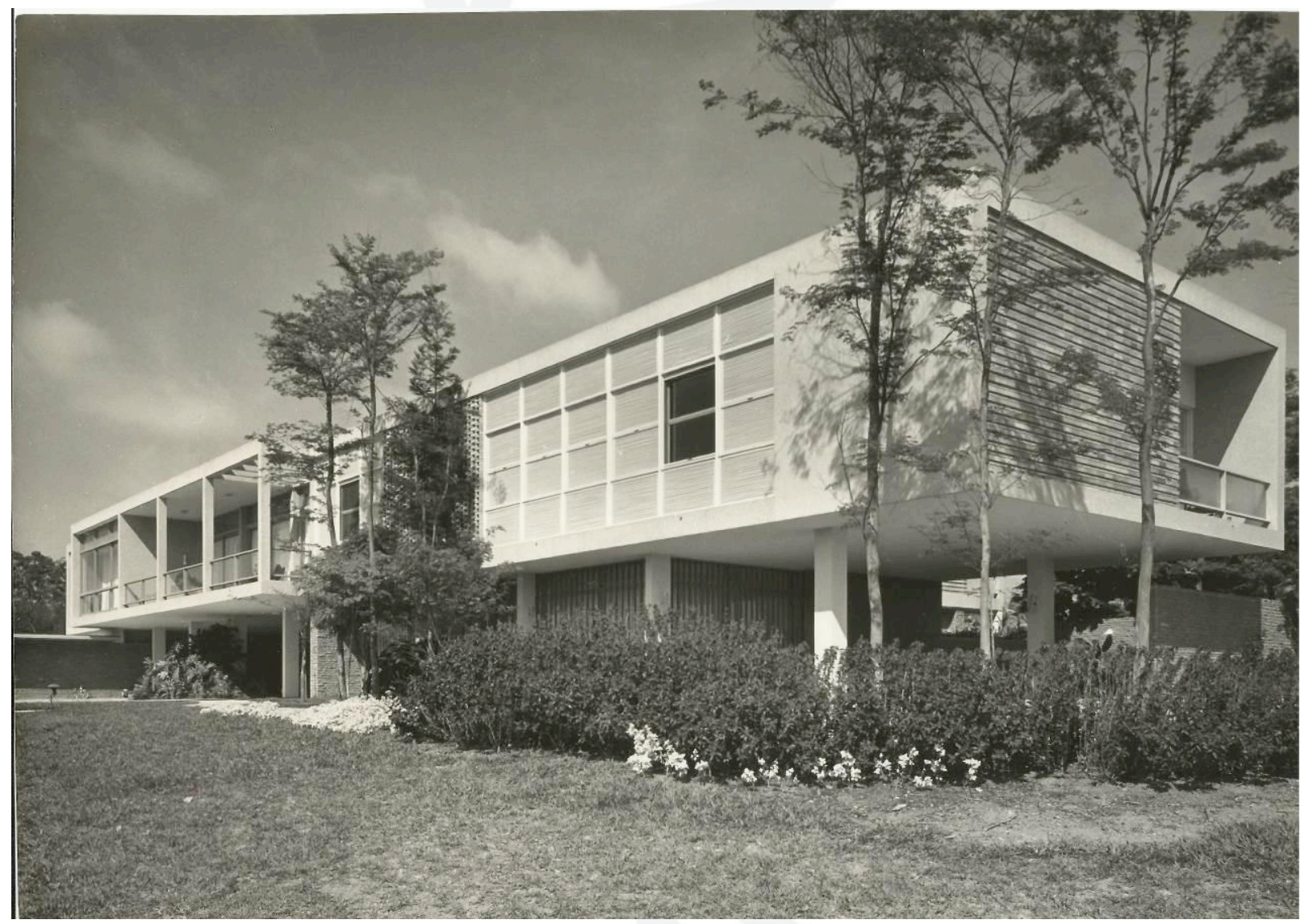

Figura 2: Fachada, Peter Scheier. Fonte: Arquivo da FMLOA. 


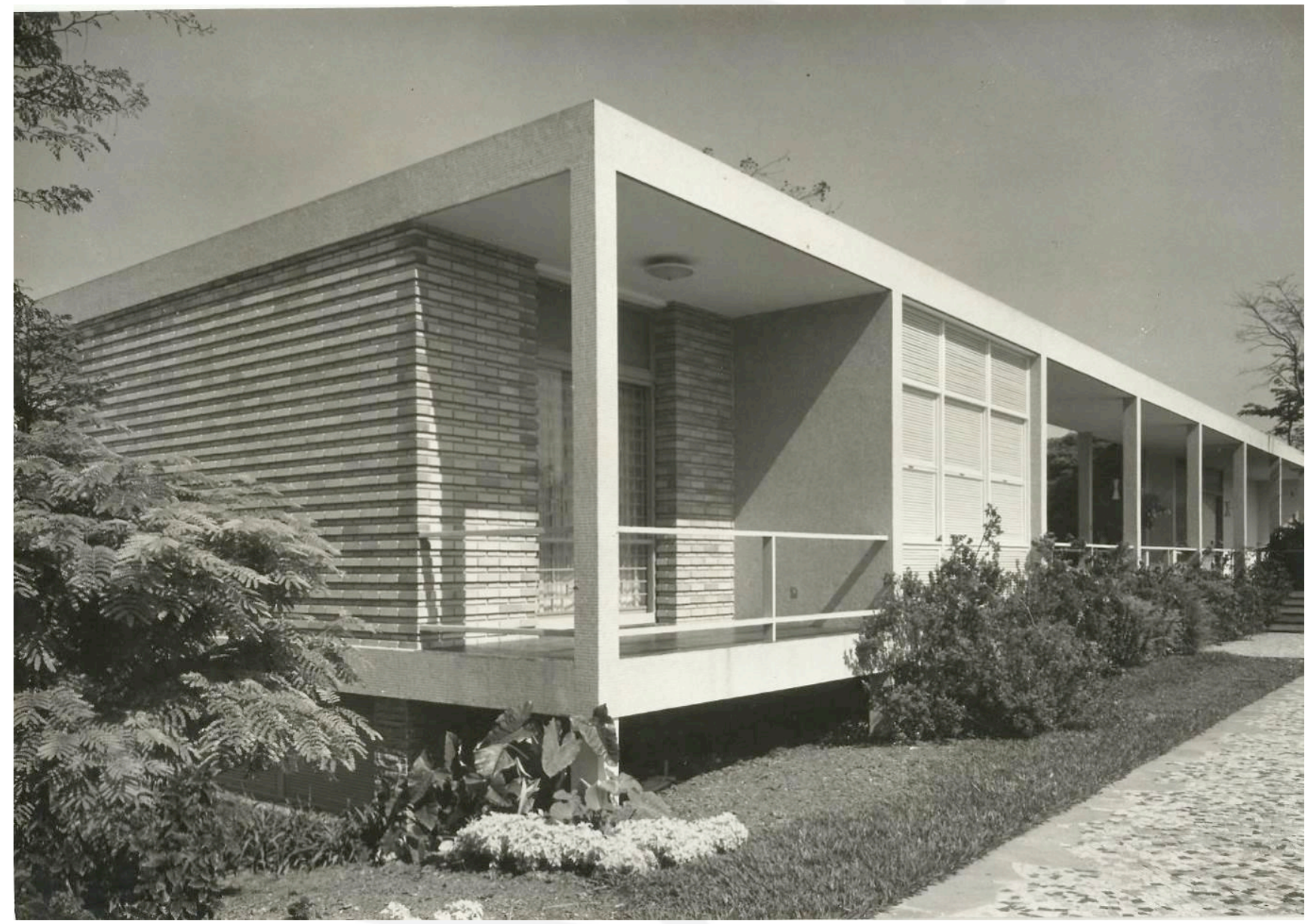

Figura 3: Fachada, Peter Scheier. Fonte: Arquivo da FMLOA. 


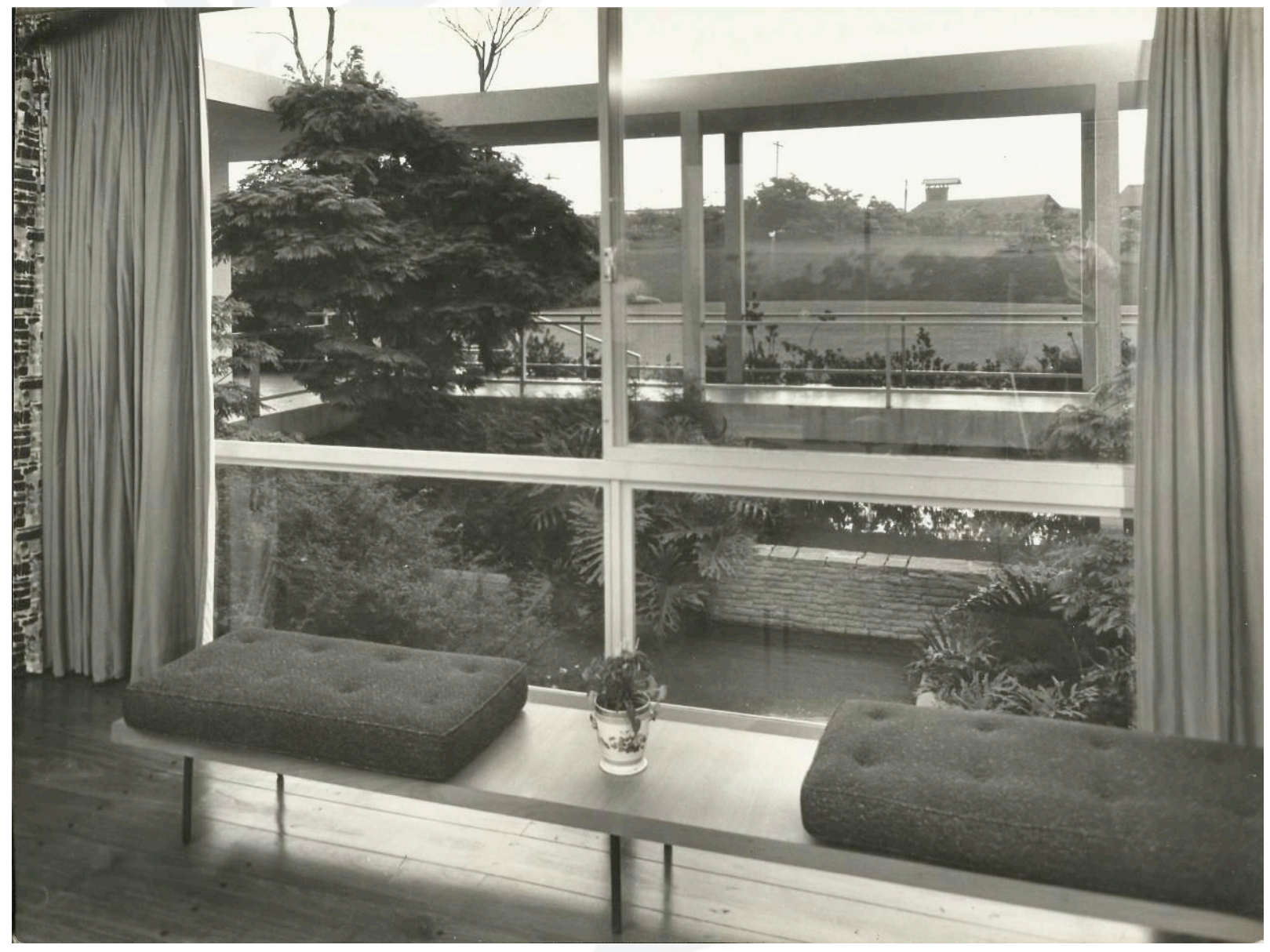

Figura 4: Espelho d'água visto da sala de estar, Leon Liberman. Fonte: Arquivo da FMLOA. 


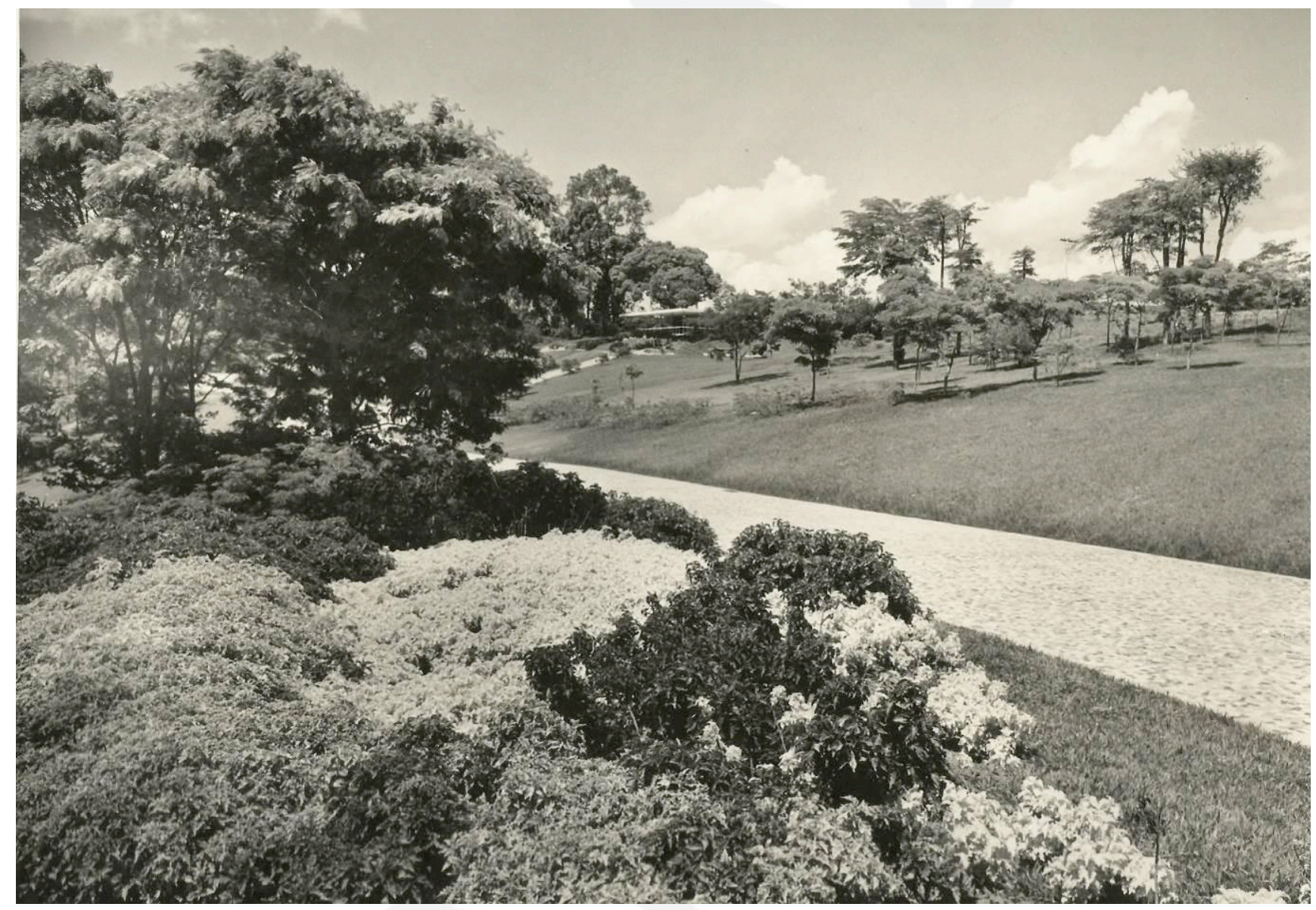

Figura 5: Jardim e pavilhão, Peter Scheier. Fonte: Arquivo da FMLOA. 


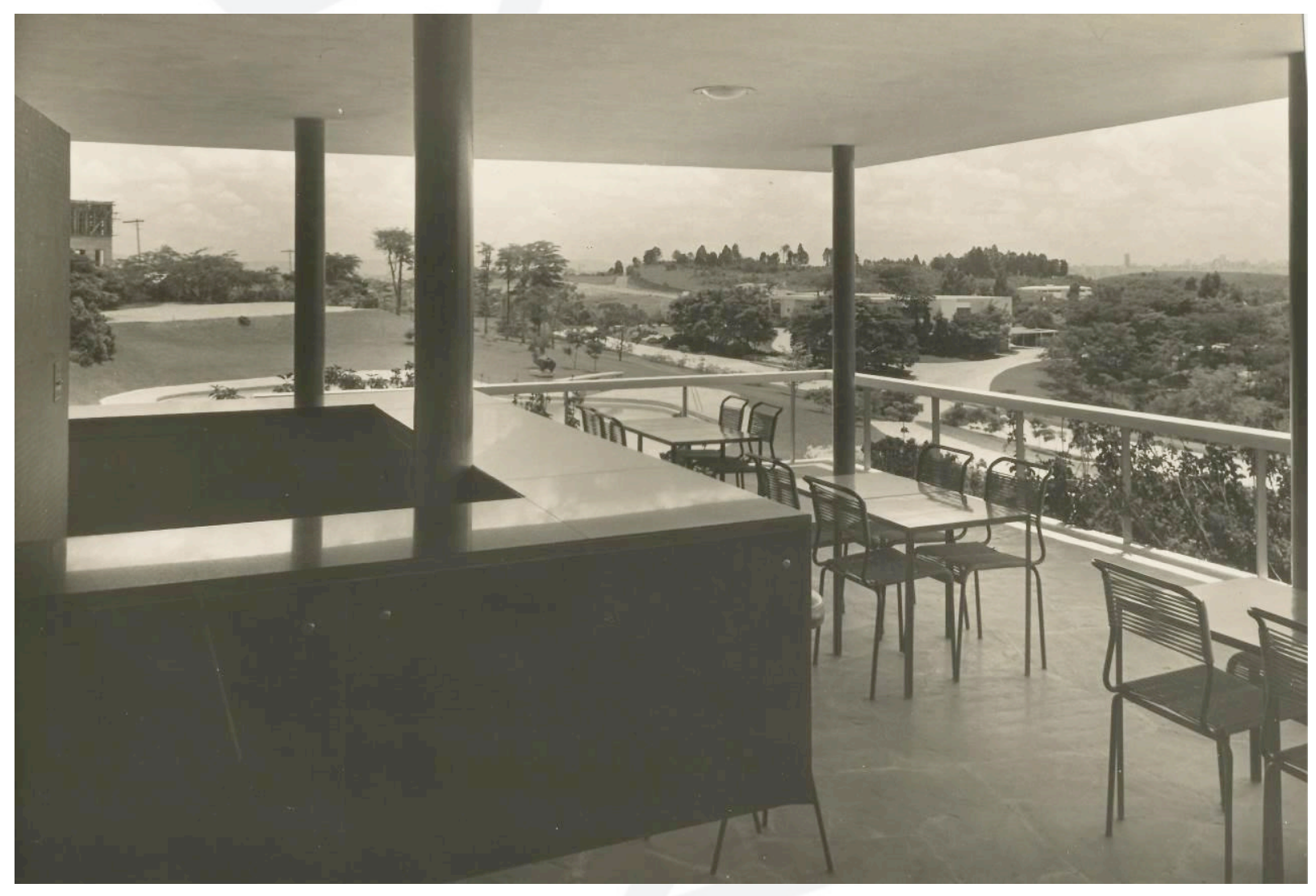

Figura 6: Jardim visto do pavilhão, Peter Scheier. Fonte: Arquivo da FMLOA. 


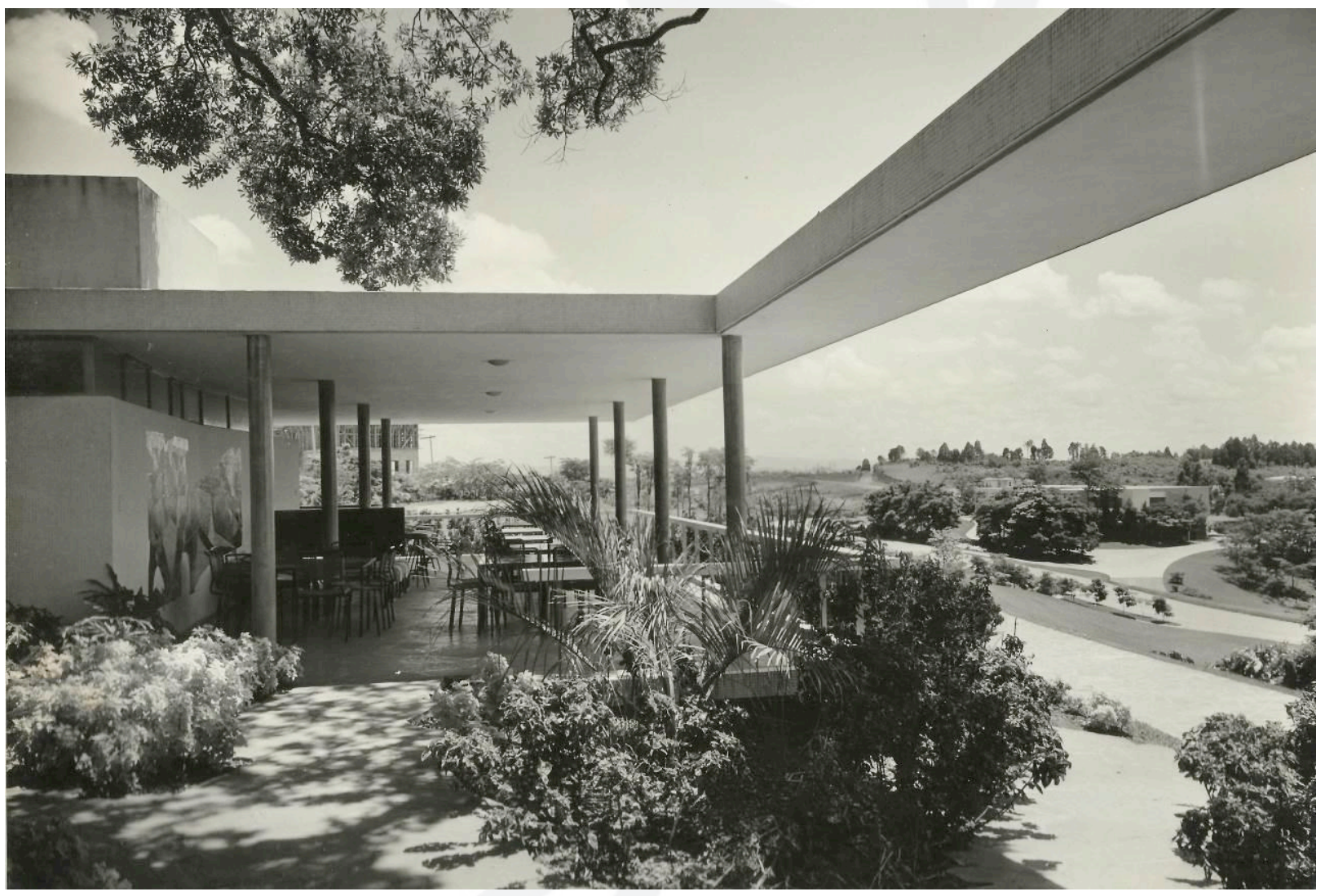

Figura 7: Pavilhão e jardim, Peter Scheier. Fonte: Arquivo da FMLOA. 


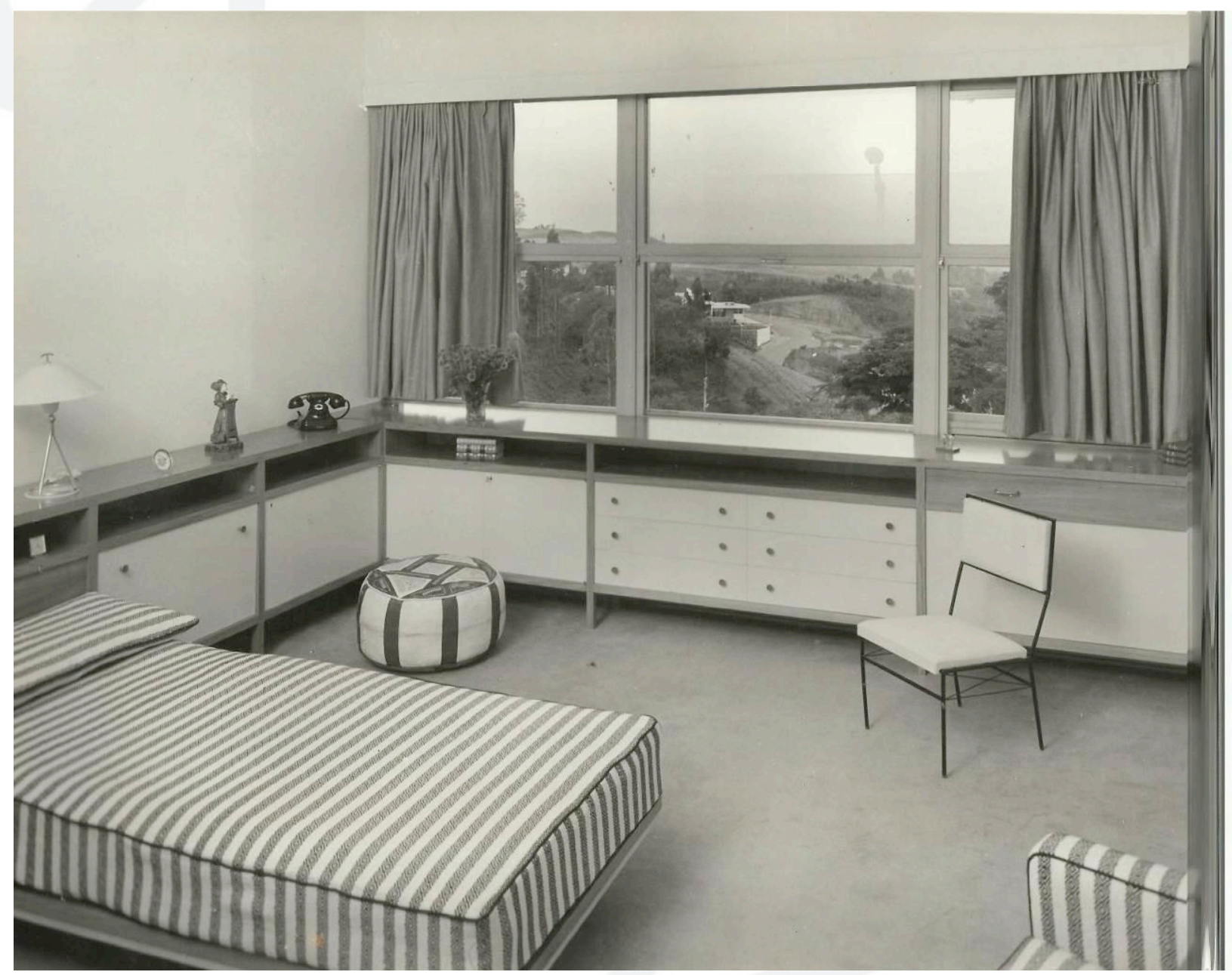

Figura 8: Interior de dormitório 1, Peter Scheier. Fonte: Arquivo da FMLOA. 


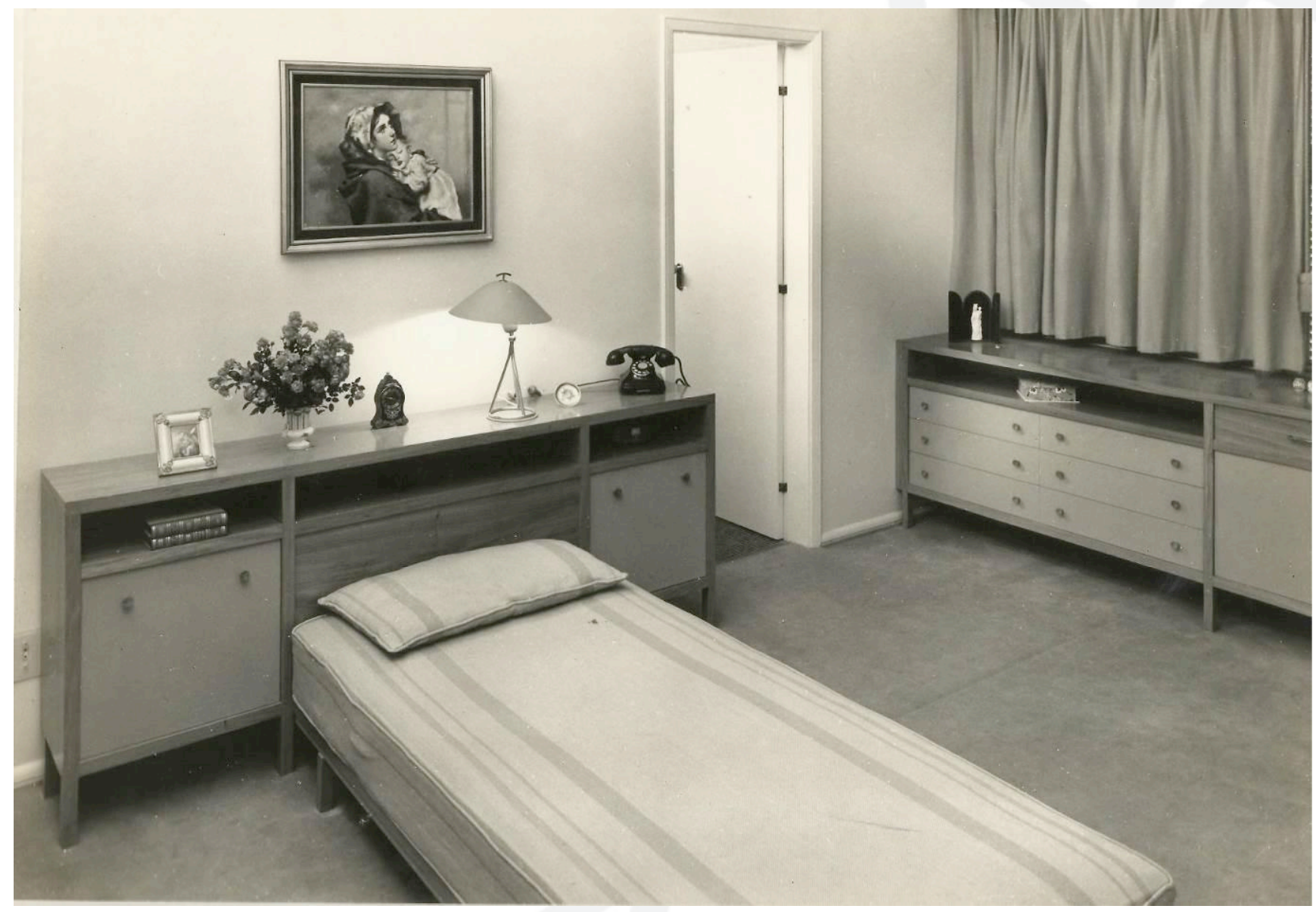

Figura 9: Interior de dormitório 2, Peter Scheier. Fonte: Arquivo da FMLOA. 


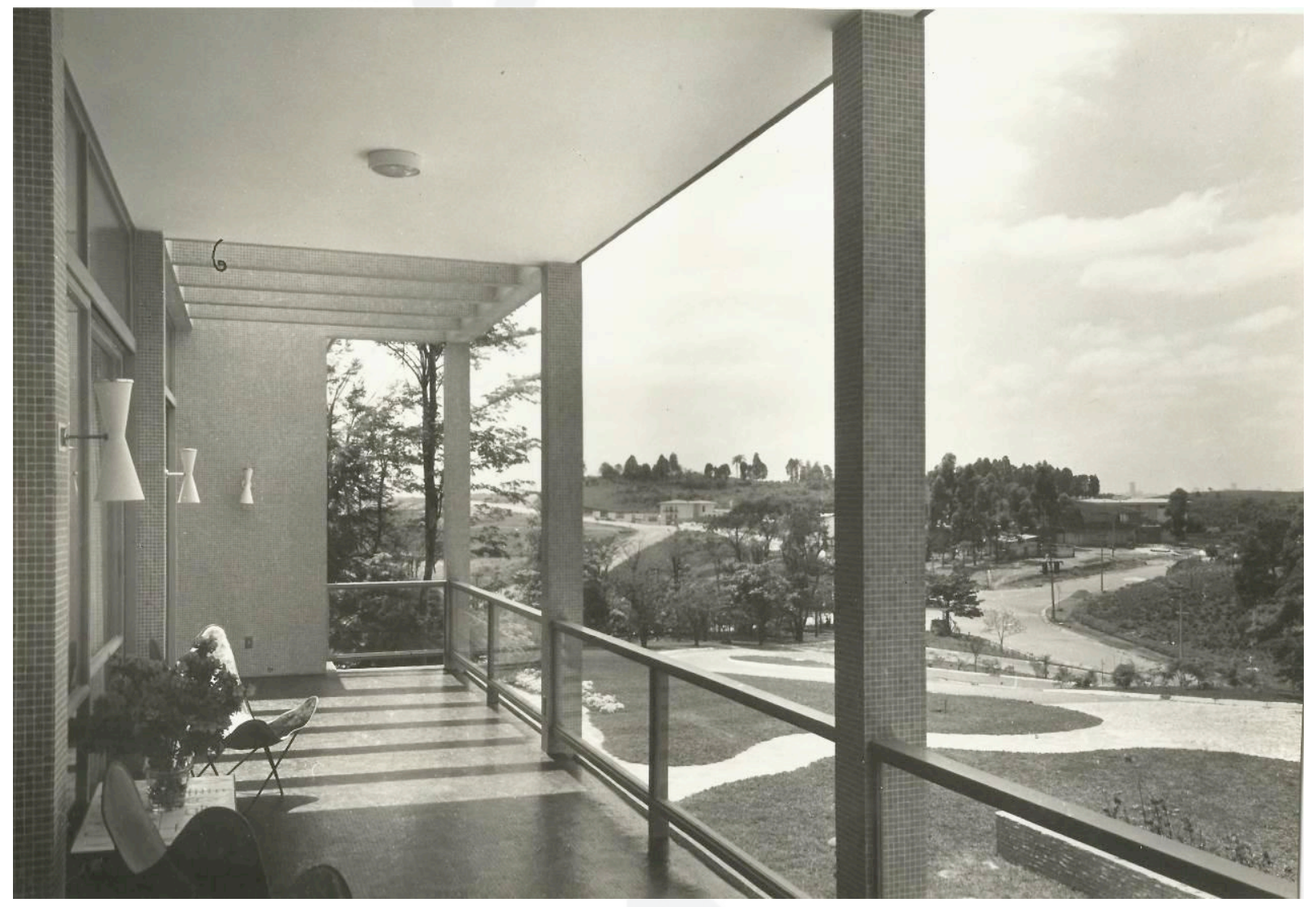

Figura 10: Jardim visto da varanda, Leon Liberman. Fonte: Arquivo da FMLOA. 


\section{CONCLUSÕES}

O que se desloca nestas imagens puras, editadas, desabitadas? Que movimentos nelas se expressam? Certo anseio por um futuro pleno, presente também em outras manifestações do período, a ser alcançado na arquitetura por meio do uso de novas tecnologias construtivas que possibilitariam a materialização de um desenho racional, ordenado como equação geométrica, justapondo cheios, vazios e texturas que emolduram vistas de um jardim pensado como natureza dominada em composição? Futuro antevisto como elemento de um ethos emulado pelas promessas do desenvolvimentismo, processo de industrialização por substituição de importações, próprio da política econômica deste momento? Composição que denotaria apropriação formal da arquitetura orgânica Wrightiana em diálogo com composições orientais somadas ao racionalismo rigoroso de Mies van der Rohe?

Propõem-se às imagens em exposição questões do presente trazidas pelo receptor, fundadas em repertório pretérito construído socialmente, numa operação que permite articular passado e futuro. É parte da missão dos museus utilizar a expografia como meio de propiciar a apreciação por ampla gama de públicos, ampliando possibilidades de interpretação.

\section{BIBLIOGRAFIA CITADA}

CHARTIER, Roger. O mundo como representação. Revista de Estudos Avançados. Instituto de Estudos Avançados da Universidade de São Paulo, 1991, v. 5, no 11, p. 173-191.

CORBUSIER, L. Por uma arquitetura. São Paulo: Perspectiva, 2011.

DIDI-HUBERMAN, Georges. O que vemos, o que nos olha. São Paulo: Editora $34,2010$.

. A imagem sobrevivente: história da arte e tempo dos fantasmas segundo Aby Warburg. Rio de Janeiro: Contraponto, 2013. 
HALL, Stuart. Codificação/decodificação. In: Sovik, L. (org.). Da diáspora: identidades e mediações culturais. Belo Horizonte: UFMG, 2003, p. 365380.

HERBST, H. Pelos salões das bienais, a arquitetura ausente dos manuais: expressões da arquitetura brasileiras expostas nas bienais paulistanas (1951-1959), Ano de Depósito. Tese (Doutorado em 2007). Faculdade de Arquitetura e Urbanismo da Universidade de São Paulo - FAUUSP, São Paulo, 2007.

\section{LISTA DE FIGURAS}

Figura 1: Fachada, Peter Scheier.

Fonte: Arquivo da FMLOA. - pág.: 132

Figura 2: Fachada, Peter Scheier.

Fonte: Arquivo da FMLOA. - pág.: 133

Figura 3: Fachada, Peter Scheier.

Fonte: Arquivo da FMLOA. - pág.: 134

Figura 4: Espelho d'água visto da sala de estar, Leon Liberman.

Fonte: Arquivo da FMLOA. - pág.: 135

Figura 5: Jardim e pavilhão, Peter Scheier.

Fonte: Arquivo da FMLOA. - pág.: 136

Figura 6: Jardim visto do pavilhão, Peter Scheier.

Fonte: Arquivo da FMLOA. - pág.: 137

Figura 7: Pavilhão e jardim, Peter Scheier.

Fonte: Arquivo da FMLOA. - pág.: 138

Figura 8: Interior de dormitório 1, Peter Scheier.

Fonte: Arquivo da FMLOA. - pág.: 139

Figura 9: Interior de dormitório 2, Peter Scheier.

Fonte: Arquivo da FMLOA. - pág.: 140

Figura 10: Jardim visto da varanda, Leon Liberman.

Fonte: Arquivo da FMLOA. - pág.: 141 